\title{
Y-sukupolvi oppijoina työssä ja elämässä
}

Pirkko-Liisa Vesterinen ja Marjaana Suutarinen (toim. 2011). Y-sukupolvi työlelämä)ssä. JTO, 181 sivua

TUtustuin Y-sukupolveen käsitteenä ensimmäisen kerran 10.11.2011 tutkimuspäivillä Helsingissä, jossa kirjan toimittajat Pirkko-Liisa Vesterinen ja Marjaana Suutarinen kertoivat Y-sukupolvesta. Esitykset olivat vaikuttavia ja lisätiedon tarpeen tyydytti heidän toimittamansa kirjan lukeminen.

Y-sukupolvea (vuosina 19802000 syntyneet) kutsutaan usein diginatiiveiksi. He ovat syntyneet digitaaliseen internetaikaan. Suomessa katsotaan olevan tällä hetkellä neljä erilaista sukupolvea: veteraanit v. 1922-1943 syntyneet, sodanjälkeiset suuret ikäluokat vuosina 1944-1960 syntyneet ja edellisiä koulutetumpi X-sukupolvi eli vuosina 1961-1979 syntyneet sekä Y-sukupolvi, vuosina 1981-2000 syntyneet.

Diginatiivi oppii, viihtyy ja ra- kentaa maailmankuvaansa verkostoissa, tiimit kohtaavat verkostoissa ja sosiaalisessa mediassa. Diginatiivilla on kännykkä kasvanut käteen kiinni ja iPodin kuulokkeet korviin, mikro ja nettiyhteys ovat aina mukana. Y-sukupolvesta vain 40 prosenttia katsoo televisiota tai lukee sanomalehtiä ja kirjoja, kaikki tarvittava tieto löytyy netistä. Tämä kannattaisi ottaa huomioon markkinoinnissa ja keskittyä sosiaaliseen mediaan. Y-sukupolvesta on tehty jo monta tutkimusta, kirjoitettu kirjoja, tehty tv-ohjelmia ja ollut artikkeleita sanoalehdissä ja tiedelehdissä. Syynä on se, että Y-sukupolvi asettaa uusia haasteita koulutukselle, työorganisaatioille ja johtamiselle. Diginatiivi etsii tietoa verkosta ja herkästi "äänestää jaloillaan”, jos esimerkiksi koulutus ei vastaa odotuksia. Tämä näkyy tietysti koulutusten vetovoimassa, keskeyttämisissä ja läpivirtauksessa.

Vesterisen ja Suutarisen toimittamassa kirjassa Y-sukupolvea tarkastellaan muiden muassa koulutusorganisaatioiden, pörssiyhtiöiden, työnantajien, puolustusvoimien, työterveyslaitoksen ja kansainvälisestä näkökulmasta. Kirjan lopussa on esitelty kuusi tapausta erilaisista yrityksistä. Kaikissa kirjoituksissa nousi esille Y-sukupolven hyvät tietotekniset ja sosiaalisen median käyttövalmiudet. Työorganisaatioissa Y-sukupolvi asettavat haasteita johtamiselle, motivoinnille, palautteelle ja työaikojen noudattamiselle.

Oppilaitoksessa toimivalle Heikki Toivasen artikkeli Jyväskylän ammattikorkeakoulun Tiimiakatemian toiminnasta oli mielenkiintoinen. Nuorten opettamisessa epäopettaminen eli 
valmentaminen on nousemassa keskiöön. Nettisukupolvi arvostaa valinnan vapautta, he toimivat yhdessä ja pitävät keskusteluista ei luennoinnista. Innovointi kuuluu heidän elämäänsä. Tiimiakatemiassa opiskelijat oppivat tekemällä käytännön liiketoimintaa, lukemalla uusimpia liiketoimintakirjoja ja käymällä dialogia tiimin kanssa. Uudenlaisia yhdessä tekemisen muotoja ovat talkoistaminen, virtuaaliset kohtaamiset ja sosiaalinen media, joissa ongelmia ratkaistaan yhteisön osaamista hyödyntäen. Toivasen mukaan edutainment eli koulutuksen ja viihteen yhdistelmä alkaa olla jo arkipäivää.

Risto Korhonen Pariisista on sitä mieltä, että Y-sukupolven tulevaisuus riippuu globaalista kehityksestä. Aikakauden mahdollisuudet ja uhat muokkaavat olennaisesti jokaista sukupolvea. Downshifting on suosittu teema nuorten keskuudessa, he eivät halua tehdä töitä samalla tavalla kuten vanhempansa. Taloustilanteen mahdollisesti edelleen heikentyessä onkin tehtävä enemmän töitä että säilyttää nykyisen elintasonsa. Toisaalta Etelä-Euroopassa Y-sukupolven suurimpana ongelmana on korkea ja jatkuvasti kasvava nuorisotyöttömyys. Kova kilpailu jokaisesta avoimesta työpaikasta myös alentaa tuntuvasti palkkatasoa. Korhosen mukaan yhteistä Euroopan kriisimaille on suuri "menetetyn sukupolven" riski. Monilla nuorilla ei tunnu olevan elämässään mitään muuta pysyvää kuin tatuointi. Turhautuneet nuoret järjestävät mielenosoituksia sosiaalisen median kautta. Aasian osaavan Y-sukupolven asenteet elämään ja työhön ovat täysin erilaiset kuin Euroopassa. Länsimaiset nuoret tulevat kilpailemaan näiden super-kunnianhimoisten ja työlleen omistautuneiden ikätovereiden kanssa. Korhonen pohtiikin artikkelissaan muuttuuko johtaminen vai muuttuuko Y-sukupolvi.

Pirkko-Liisa Vesterinen pohtii artikkelissaan Y-sukupolvea johdettavana. Nykyisen johtajan on osattava johtaa eri sukupolvia eri tavoin ja saatava eri sukupolvet ymmärtämään toisiaan sekä työskentelemään yhdessä täydentäen toinen toisensa osaamista. Ysukupolven myötä organisaation toimintatapojen ja työmenetelmien on uudistuttava, on panostettava työntekijöiden hyvinvointiin. Y-sukupolvi arvostaa työyhteisön hyvää ilmapiiriä, viihtyisää työympäristöä, hyvää johtamista ja esimiestyötä, työn mielekkyyttä ja esimiehen innostavuutta sekä reiluutta. Nuoret haluavat käyttää enemmän ajastaan harrastuksiin ja sosiaaliseen elämään. Y-sukupolvi haluaa käyttöönsä uusimmat IT-ratkaisut ja -sovellukset. He ovat tottuneet saamaan jatkuvasti (positiivista) palautetta. Johtamiselle Y-sukupolvi tuo haasteita erityisesti työelämätaitojen puutteen osalta esim. työaikoja voidaan tulkita hyvinkin joustavasti. Nykysukupolvea johdetaan coachaamalla.

Tapauskertomuksissa tarkastellaan nuoren johtajan kokemuksia, kokemuksia nuorista työntekijöistä ja nuoret näkemyksiä työntekijänä olosta. Lisäksi on tapaus perheyrityksestä, jossa Ysukupolvi on mukana.

Kaiken kaikkiaan kirja herätti runsaasti ajatuksia. Joutui pohtimaan miten korkeakoulussa kohdataan Y-sukupolvi sekä opiskelijoina että työntekijöinä ja miten eri sukupolvien väliset erilaisuudet saadaan yhteen sovitettua. Kirjassa tarkastellaan Y-sukupolvea niin monesta eri näkökulmasta, että asiasta saa todella monipuolisen kuvan.

Raijaliisa Laakkonen

$F T, K L$, opetusjohtaja

Vaasan ammattikorkeakoulu 